\title{
Dissociated Cingulate Cortical Neurons: Morphology and Muscarinic Acetylcholine Receptor Binding Properties
}

\author{
Brent A. Vogt, Ellen Townes-Anderson, ${ }^{1}$ and David L. Burns \\ Departments of Anatomy and Physiology, Boston University School of Medicine, Boston, Massachusetts 02118, and \\ 'Department of Physiology, Cornell University Medical College, New York, New York 10021
}

Identifiable cortical neurons were obtained from area $29 \mathrm{c}$ of rat cingulate cortex using enzymatic and mechanical dissociation techniques. Dissociated neurons were either analyzed morphologically with the electron microscope or processed autoradiographically to evaluate the distribution of specific ${ }^{3} \mathrm{H}$-propylbenzilylcholine mustard (PrBCM) binding. Ultrastructurally, neurons appeared healthy and contained a full complement of cytoplasmic organelles. Membranes were intact and no presynaptic endings adhered to cell bodies or dendrites. Dendritic spines were not observed in these dissociations and serial sections of identified neurons indicated that all dendritic processes were smooth.

Receptor binding studies were conducted on small and medium-to-large pyramidal neurons and multipolar cells. Specific binding of PrBCM was determined by calculating the mean number of grains $/ 10 \mu \mathrm{m}$ somal perimeter or dendritic length and subtracting mean values from a matched series of neurons that were coincubated in atropine. Specific binding was to somata and dendrites of all neurons. Nonspecific binding was an average of $33 \%$ of total binding. A $2 \times 2$ factorial analysis of variance comparing total and nonspecific binding for pairs of processes indicated that there were no regional differences in dendritic binding, either by cell type or by order of dendritic branching. Both somatic and dendritic PrBCM binding was antagonized by pirenzepine (PZ); however, PZ appeared to be more effective at secondary dendritic, rather than at somatic and primary apical dendritic sites. Thus, the $I_{50}$ values for somata and primary apical dendrites of small pyramids were $6 \times 10^{-7}$ and $9 \times 10^{-7} \mathrm{M} \mathrm{PZ}$, respectively, while that for secondary basal dendrites of the same neurons was $5.8 \times 10^{-8} \mathrm{M}$.

Morphological and pharmacological results together suggest that (1) muscarinic receptors are present on the smooth surfaces of all pyramidal and multipolar neurons; (2) many of the binding sites are high affinity, PZ-sensitive, $M_{1}$ receptors; and (3) this binding is associated with the postsynaptic specialization of symmetric, cholinergic synapses.

Regional analyses of muscarinic acetylcholine receptor (AChR) binding in mammalian central nervous system have employed light-microscopic autoradiographic techniques (Yamamura et

\footnotetext{
Received Mar. 13, 1986; revised Aug. 22, 1986; accepted Scpt. 22, 1986.

This research was supported by NIH Grants 18745 and E406135.

Correspondence should be addressed to Brent A. Vogt, Departments of Anatomy and Physiology, Boston University School of Medicine, 80 East Concord Street, Boston, MA 02118.

Copyright $(C) 1987$ Society for Neuroscience $0270-6474 / 87 / 040959-13 \$ 02.00 / 0$
}

al., 1974; Kuhar and Yamamura, 1976; Rotter et al., 1979; Wamsley et al., 1981; Lang and Henke, 1983; Palacios et al., 1986). These studies demonstrated which brain stem nuclei and cortical laminae have AChR, but did not address the question of which cells and axonal inputs these receptors are associatcd with. Biochemical studies have identified presynaptic muscarinic receptors (Fisher et al., 1981; Raiteri et al., 1984; Mash et al., 1985; Meyer and Otero, 1985), as well as AChR associated with microvasculature (Estrada et al., 1983) and cultured glial (Repke and Maderspach, 1982) cells, but direct visualization of the cellular location of these receptors was not possible. An electron-microscopic autoradiographic study of cortical AChR (Kuhar et al., 1981) suggested that these sites are associated with synapses; however, this technique cannot be used to establish specific associations with pre- or postsynaptic elements.

Cellular localization issues are particularly important in light of recent attempts to categorize subtypes of $A C h R$, since one of the principal distinctions could be cell process location. The cerebral cortex has 2 varieties of muscarinic receptors (Wamsley et al., 1980; Luthin and Wolfe, 1984). First, there is a high affinity or $\mathrm{M}_{1}$ site that has been labeled with pirenzepine (PZ) in regional localization studies (Wamsley et al., 1984; Watson et al., 1986). This receptor may be postsynaptic because electrophysiological studies have shown that ACh-evoked, slow depolarization of pyramidal cells is mediated via a PZ-sensitive receptor (McCormick and Prince, 1985, 1986), and neurotoxin lesions, which destroy cortical neurons, greatly reduce ${ }^{3} \mathrm{H}-\mathrm{PZ}$ binding in cingulate cortex (Vogt, 1985b; Vogt et al., 1986). There is also evidence that $\mathrm{PZ}$-sensitive sites undergo axonal transport (Watson et al., 1986); thus these receptors may not be limited to postsynaptic elements. Second, there is a low affinity or $\mathrm{M}_{2}$ site that is presynaptic, according to a number of biochemical studies (Raiteri et al., 1984; Mash et al., 1985; Meyer and Otero, 1985), and we have suggested that presynaptic receptors on axons of anterior thalamic afferents to cingulate cortex are of the $\mathrm{M}_{2}$ variety (Vogt et al., 1986). Evidence for a postsynaptic $\mathrm{M}_{2}$ site has also been proposed for multipolar neurons (McCormick and Prince, 1986).

It is still not known where on the neuron (i.e., soma, primary, secondary, and/or tertiary dendrites) muscarinic receptors are located. Isolated neurons provide a direct means of visualizing the distribution of receptors on identified types of cells. Neurons from adult retina have been dissociated for analysis of phototransduction, process regencration, and synaptic vesicle membrane recycling (Bader et al., 1979; MacLeish et al., 1983; Townes-Anderson et al., 1985).

The rationale of the present study was as follows. First, an electron-microscopic analysis of the integrity of dissociated neu- 
rons was made as the basis for interpreting receptor binding observations. Second, the tritiated ligand propylbenzilylcholine mustard (PrBCM) was used to localize muscarinic receptors, since it binds to them irreversibly (Young et al., 1972; Burgen et al., 1974). Thus, dissociated neurons incubated in PrBCM may be dipped into warm photographic emulsion for autoradiography without subsequent dissociation of PrBCM from the receptor. Finally, in order to assess receptor subtype, unlabeled $\mathrm{PZ}$ was used to compete with PrBCM at $\mathrm{M}_{1}$ sites. Although it was done under nonequilibrium conditions, this approach has proven useful in experimental studies localizing muscarinic subtypes with cryomicrotome sections of cingulate cortex (Vogt et al., 1986).

\section{Materials and Methods}

Dissociation. Postwean (50-150 gm) male hooded Long-Evans rats werc killed by decapitation, the brain removed and placed in a cooled $\left(15^{\circ} \mathrm{C}\right)$ chamber. A wedge of posterior cingulate cortex containing the bulk of area $29 \mathrm{c}$ was dissected, as is depicted in Figure 1 . The white matter and a small part of cortex, including layer VI, were removed and the remaining block sectioned into 5-7 coronal pieces. In groups of 3, the blocks were placed at room temperature for $30 \mathrm{~min}$ in $14 \mathrm{ml}$ oxygenated $\left(95 \% \mathrm{O}_{2} / 5 \% \mathrm{CO}_{2}\right)$ enzyme solution that contained (in $\mathrm{mm}$ ) $\mathrm{NaCl}, 120 ; \mathrm{KCl}, 3 ; \mathrm{NaHCO}_{3}, 25 ; \mathrm{Na}_{2} \mathrm{HPO}_{4}, 0.8 ; \mathrm{NaH}_{2} \mathrm{PO}_{4} \cdot \mathrm{H}_{2} \mathrm{O}, 0.1$; $\mathrm{CaCl}, 2$; glucose, 10; 196 units papain (Cooper Biomedical), and $6 \mathrm{mg}$ DL-cysteine (Sigma). The tissue in enzyme solution was then heated to $30^{\circ} \mathrm{C}$ and agitated for $30 \mathrm{~min}$. The blocks were washed 3 times at room temperature with oxygenated Dulbecco's Modified Eagle's Medium Nutrient Mixture F-12 Ham (Sigma) containing sodium bicarbonate (15 mm) and NuSerum (10\%; Collaborative Research). A large-bore, $5 \mathrm{ml}$ glass pipctte was used to triturate the sections 30-60 times. The solution usually turned cloudy when cell dispersal occurred. A sample of the solution was checked with phase-contrast optics to verify the presence of dissociated and healthy neurons. Concanavalin A (Con-A)-coated slides were prepared by dissolving $10 \mathrm{mg} / \mathrm{ml}$ Con-A in $1 \mathrm{M} \mathrm{NaCl}$ and placing 100-200 $\mu$ l onto slides for $2 \mathrm{hr}$. In some instances the Con-A was simply poured from the slide before use, while at other times the slides were rinsed 1 or 2 times with culture medium.

Electron microscopy. Cells, maintained either in suspension or arranged as a monolayer by plating them onto Con-A-coated mica coverslips, were fixed 1 or $2 \mathrm{hr}$ following dissociation. If fixed in suspension, the cells were pelleted after primary fixation and subsequently processed as a pellet; if fixed as a monolayer, cells that attached to the coated coverslips were processed and the mica coverslips removed after plastic embedding. The primary fixative was $2.5 \%$ glutaraldchydc, $2.5 \%$ paraformaldehyde, and $0.05 \%$ picric acid in $0.1 \mathrm{M}$ cacodylate buffer, $\mathrm{pH} 7.4$ (Ito and Karnovsky, 1968). Postfixation was performed in a solution of $1 \% \mathrm{OsO}_{4}$ and $1.5 \%$ potassium ferrocyanide (Karnovsky, 1971). Cells were then stained en bloc with $1 \%$ uranyl acetate in maleate buffer, dehydrated, and embedded in an Epon-Araldite mixture. To section identified cells, neurons were selected from the embedded monolayers, camera lucida drawings were made, and the individual neurons serially sectioned and placed on 300-mesh Slim-Bar grids (Structure Probe, West Chester, PA); during electron-microscopic examination, the locations of all micrographs were recorded on the drawings. Sections from both pellets and monolayers were stained with uranyl acetate and lead citrate and viewed in a JEOL- $100 \mathrm{C} \times 2$ electron microscope.

Receptor binding assay. Cells were allowed to settle on Con-A-coated slides for 1-2 hr to ensure a strong cell-substrate adhcsion. The protocol for the assay of PrBCM binding was the same as that for slide-mounted cryostat microtome sections (Vogt, 1984). This included a light prefixation with $0.1 \%$ glutaraldehyde in Krebs-Henseleit buffer $(\mathrm{K}-\mathrm{H})$ at $5^{\circ} \mathrm{C}$ for $15 \mathrm{~min}, \mathrm{~K}-\mathrm{H}$ rinse (room temperature, $5 \mathrm{~min}$ ), $2 \mathrm{~K}-\mathrm{H}$ preincubations $\left(30^{\circ} \mathrm{C}, 15 \mathrm{~min}\right.$ each), incubation in PrBCM (2.4 nM; New England Nuclear, specific activity $=43 \mathrm{Ci} / \mathrm{mm} ; 30^{\circ} \mathrm{C}, 15 \mathrm{~min}$ ), reaction termination with Carnoy's solution (30 min), and three 40 min washes with $100 \%$ ethanol. Nonspecific binding was determined with $10^{-6} \mathrm{M}$ atropine in 1 preincubation and the incubation solutions. In 1 series, $10^{-6} \mathrm{M} \mathrm{PZ}$ was included in the incubation medium, while for competition experiments a full range of concentrations from $10^{-4}$ to $10^{-8} \mathrm{MPZ}$ was used. Pirenzepine was kindly provided by Boehringer Ingelheim. The autoradiographic technique was also the same as that previously reported,
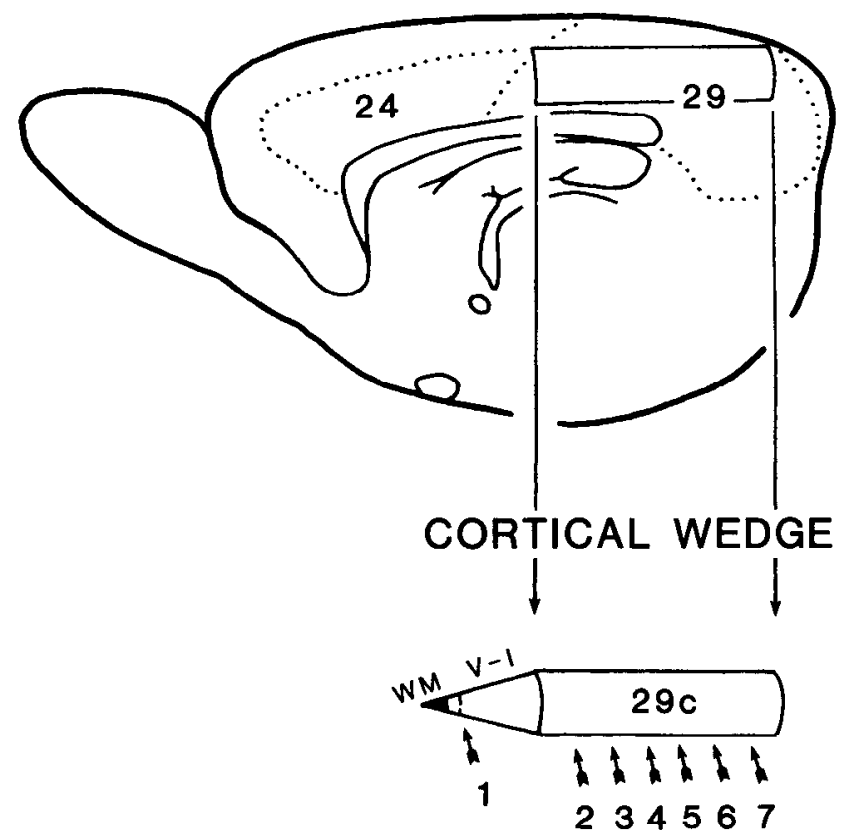

Figure 1. Medial surface of rat brain, including cytoarchitectural borders of areas 24 and 29 and the position from which wedges of area $29 c$ were removed for dissociation. Cortical wedges were further dissected by removal of white matter $(W M)$ and layer $V I$ at 1 , and then coronal sections made at 2-7.

including dipping in Kodak NTB-2 emulsion; however, exposures were quite long (4-5 months). Slides were developed in Kodak D-19 for 4$6 \mathrm{~min}$ at $20^{\circ} \mathrm{C}$ and counterstained with a Geimsa stain in Sörenson's phosphate buffer ( $\left.\mathrm{pH} 6.4,25-30^{\circ} \mathrm{C}, 10-15 \mathrm{~min}\right)$.

Quantitative analysis. All slides were systematically surveyed with light- and dark-field optics at $250 \times$. Neurons with at least primary and secondary dendrites were chosen for drawing at $980 \times$ with bright-field optics and a drawing tube. Grains were then evaluated at $650 \times$ with dark-field optics, and all grains within $3 \mu \mathrm{m}$ of the neuron plotted on these drawings. Of over 1500 neurons surveyed, almost 300 were drawn in this fashion. Neurons were not included in the final grain counts when too few examples of a cell type were found (e.g., bitufted nonpyramidal cells) or the characterization could be confused between 2 or more cell types (e.g., extraverted pyramids and typical pyramids with their apical dendrites pinched off can look quite similar). Thus, for quantitative analysis 2 cell types were studied: pyramids and multipolar neurons. Pyramidal cells were further subdivided, based on transverse somal diameter, into small $(<10 \mu \mathrm{m})$ and medium-to-large $(\geq 10 \mu \mathrm{m})$ neurons.

Once neurons were drawn and categorized, the number of grains per micrometer of somal perimeter or length of primary, secondary, and tertiary dendrite was calculated, using a Micro-Plan II Image Analysis System (Donsanto, Natick, MA). For specific binding a mean \pm SE of total binding for the somata and processes of each neuronal type was calculated and the mean \pm SE of atropine-blocked control values subtracted. These specific binding numbers were then converted to grains/ $10 \mu \mathrm{m}$ of somal perimeter or dendritic process so that whole numbers could be reported. In order to statistically assess regional differences in PrBCM binding, a $2 \times 2$ factorial analysis of variance was conducted. For this test, total and nonspecific binding were compared on 2 cell processes, either within or between cell classes. Values with a $p$ of 0.05 were considered significant. Since PrBCM does not dissociate from the receptor, one would not conduct occupancy competition studies in which $K_{\mathrm{d}} \mathrm{s}$ were estimated for each of 2 sites using computer curve-fitting techniques. Instead, $\mathrm{IC}_{50}$ values were evaluated directly from semilogarithmic plots of grain density per unit length of dendrite or somal perimeter over a range of $\mathrm{PZ}$ concentrations. Grain densities were calculated for each part (i.e., soma, primary, secondary, and tertiary dendrites) of every cell and then the means $\pm S E$ were determined for each concentration of $\mathrm{PZ}$. Specific binding was not used for competition studies because there were not enough intact neurons isolated in a single experiment to determine control values for each point. 
The Journal of Neuroscience, April 1987, 7(4) 961

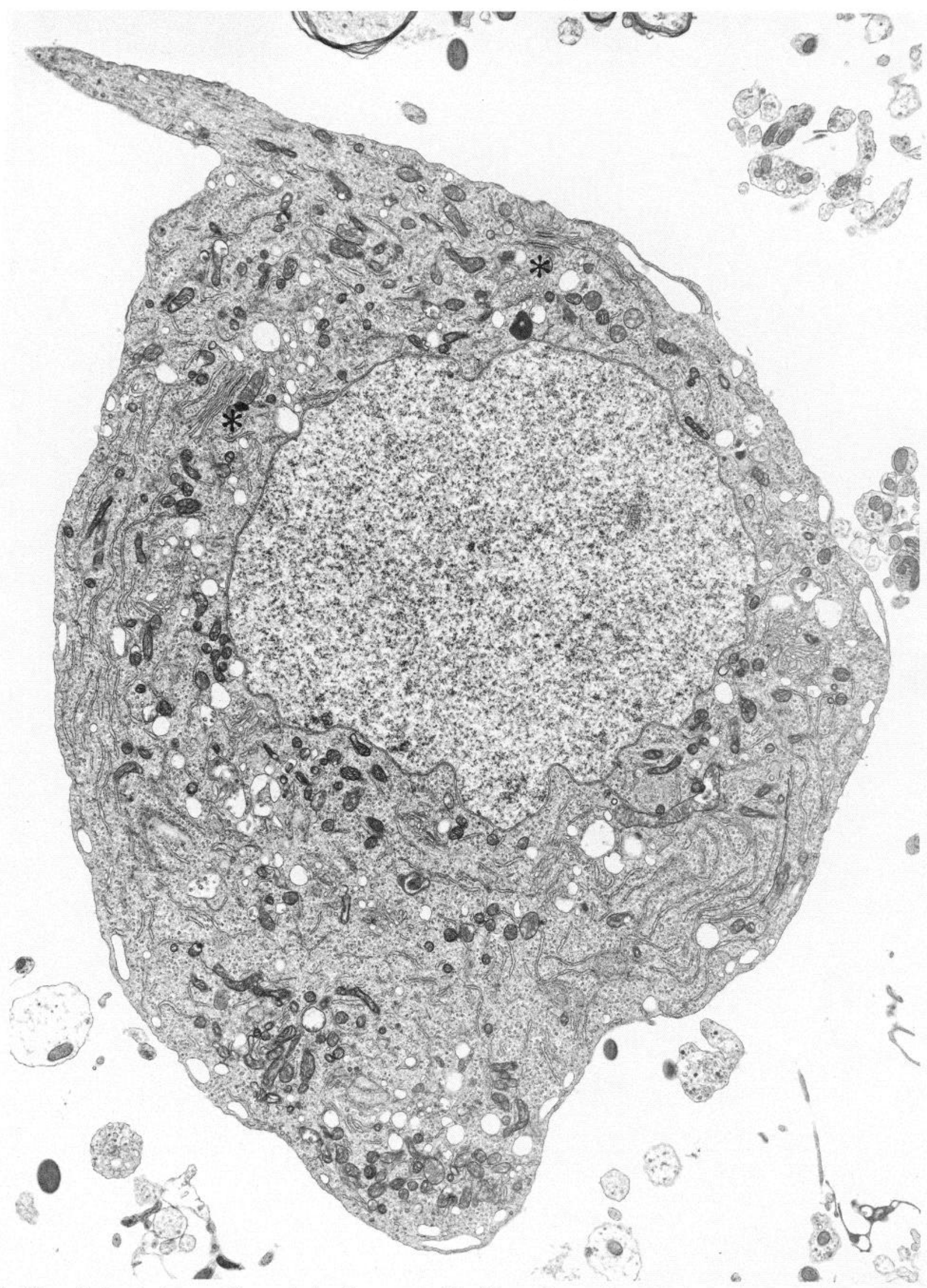

Figure 2. Dissociated cortical neuron. Neurons look well preserved, with a full complement of cytoplasmic organelles. In addition, lamellar bodies, an inclusion characteristic of cortical neurons, are present (asterisks). The isolation procedure leaves the plasmalemma intact and the cell surface free of adhering presynaptic terminals. $\times 9000$. 

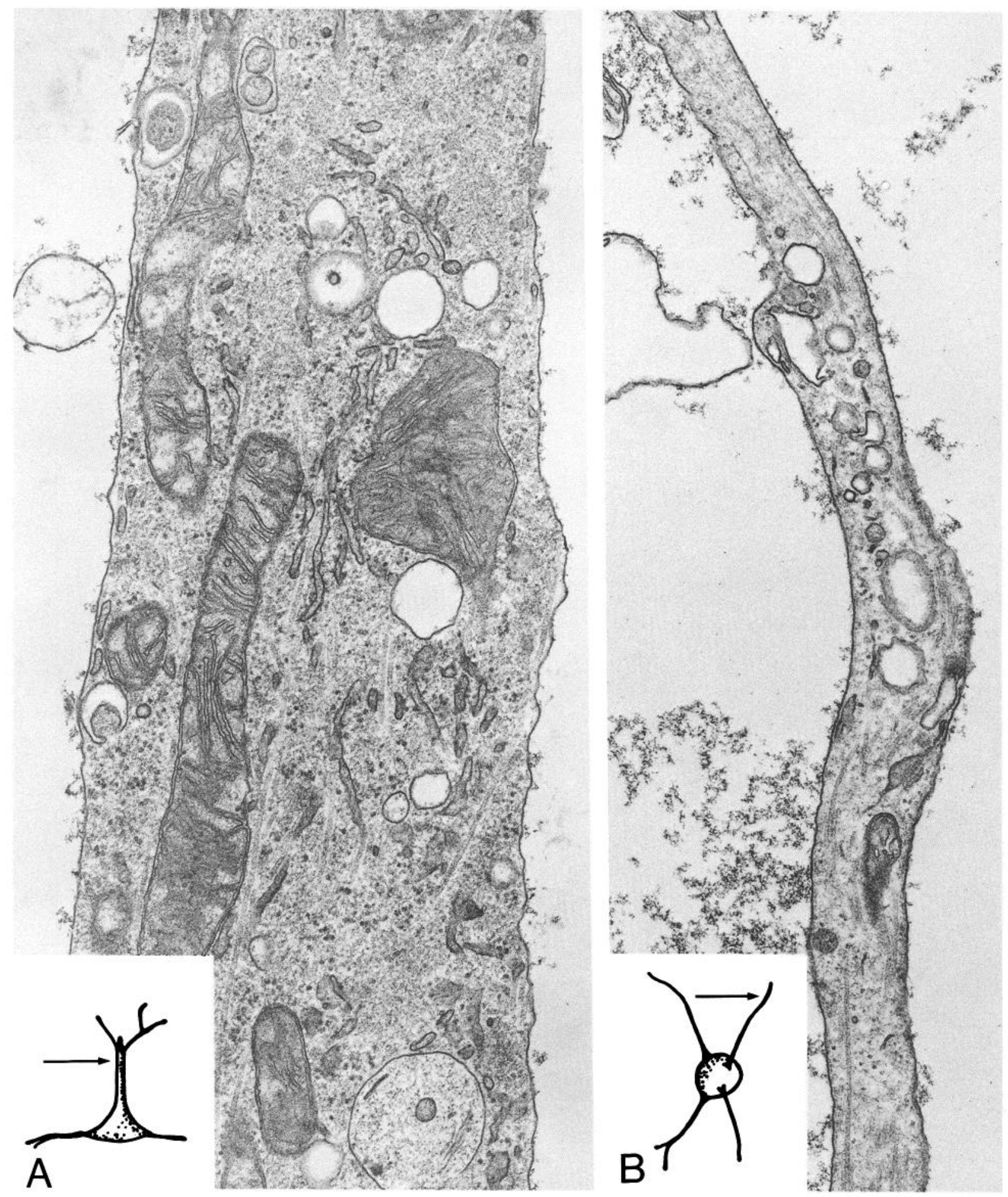

Figure 3. Dendritic processes from identified neurons. A, Apical dendrite of a medium-large pyramidal cell. $B$, Primary dendrite of a multipolar cell. The dendrites are filled with their normal complement of organelles, including microtubules. Plasma membranes are intact; however, no spines are present. $A, \times 40,000 . B, \times 34,000$.

\section{Results}

\section{Morphology of isolated neurons}

Dissociation of layers I-V from area $29 \mathrm{c}$ of rat cingulate cortex yielded a variety of neuronal and glial cells, as well as short segments of cerebral blood vessels. The identification of isolated neurons was based on previous morphological studies of the intact posterior cingulate cortex (Ramon y Cajal, 1911, 1922; Herrmann and Schulz, 1978; Kusicka and Schulz, 1981; Vogt and Peters, 1981; Vogt, 1985a). Since much of the axon, the apical dendritic tuft, and the distal dendritic tree was removed from the neurons during dissociation, the somata and proximal dendrites were the features used for cell classification. Between 125 and 150 neurons were identifiable in a dissociation that 

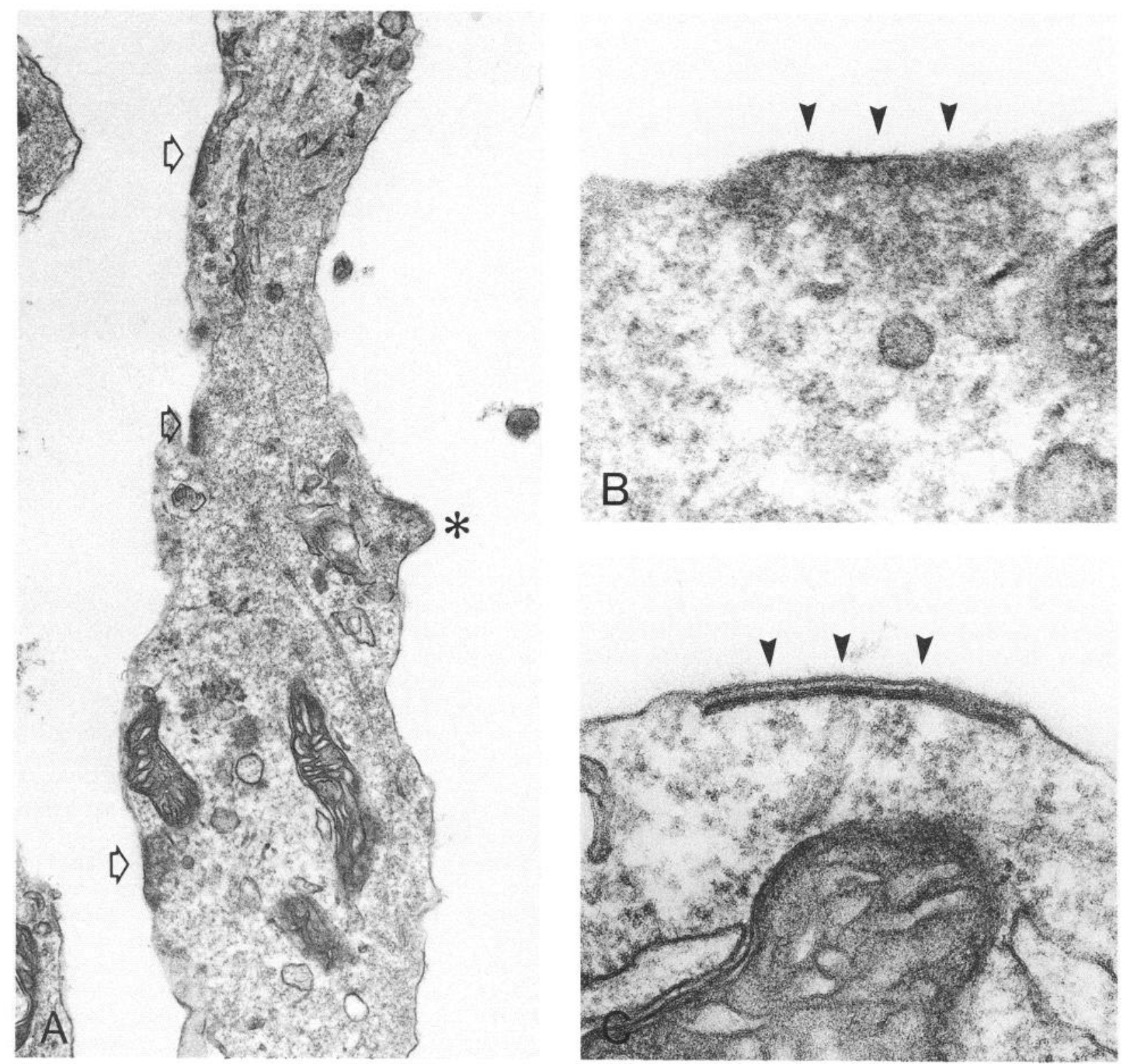

Figure 4. Membrane specializations. A, Dendritic process containing numerous postsynaptic densities (arrows). A small evagination of the surface may represent the stalk of a former dendritic spine (asterisk). B. At the postsynaptic density of a presumed former asymmetric synapse (arrowheads), the cytoplasmic surface of the plasma membrane is coated with a thick layer of dense filamentous material. $C$, Subsurface cisternae (arrowheads) are also present in dissociated neurons. A diffuse density is apparent between the cisterna and the somal plasmalemma. $A, \times 30,000 . B, \times 115,000$. $C, \times 112,000$.

included 2 animals. All neuronal types were present in the suspensions; however, pyramidal and multipolar cells were by far the most numerous. Medium-large pyramids routinely retained their pyramidal-shaped somata and conically shaped apical dendrites and basal dendrites, whereas small pyramids (somata $<10$ $\mu \mathrm{m}$ in transverse diameter) had more varied somatic shapes, from ovoid to pyramidal. Multipolar neurons had a characteristic stellate appearance, with more-or-less spherical somata and several primary dendrites that radiated in a fairly even distribution from the somata. For examples of each cell type, see Figures 5-7.

The fine structure of dissociated cortical neurons, examined 1-2 $\mathrm{hr}$ after removal from the brain, was remarkably well preserved. The somata (Fig. 2) were filled with a full complement of cytoplasmic organelles, including numerous mitochondria, endoplasmic reticulum, free ribosomes, and Golgi apparatus. In addition, lamellar bodies, a cytoplasmic inclusion characteristic of cortical neurons, were frequently observed. The dendrites (Fig. 3) also appeared normal at the ultrastructural level; they contained mitochondria, endoplasmic reticulum, ribosomes, and numerous microtubules. As in intact brain, the cytoplasmic constituents were aligned parallel to the axis of the dendrite except at the severed ending, where disruption of the internal structure was apparent. Although small vacuoles were present in somata and dendrites, swelling of cytoplasmic organelles or dilution of the cytoplasmic matrix was not a common feature of these isolated cells.

In order to ensure the validity of using dissociated neurons for receptor binding assays and to aid in the interpretation of results, a careful study was made of the cell surface and re- 
Table 1. Distribution of PrBCM binding to dissociated neurons

\begin{tabular}{|c|c|c|c|c|c|c|c|}
\hline \multirow[b]{2}{*}{ Cell type } & \multirow[b]{2}{*}{ Somata } & \multicolumn{3}{|c|}{ Apical dendrites } & \multicolumn{3}{|c|}{ Basal dendrites } \\
\hline & & $1^{\circ}$ & $2^{\circ}$ & $3^{\circ}$ & $1^{\circ}$ & $2^{\circ}$ & $3^{\circ}$ \\
\hline $\begin{array}{l}\text { Small pyramids } \\
\quad(n=24)\end{array}$ & $\begin{array}{l}2.82 \pm 0.33^{a} \\
1.88 \pm 0.21^{b} \\
0.94^{c}\end{array}$ & $\begin{array}{l}3.40 \pm 0.43 \\
1.32 \pm 0.33 \\
2.08\end{array}$ & $\begin{array}{l}4.25 \pm 0.49 \\
1.02 \pm 0.29 \\
3.23\end{array}$ & $\begin{array}{l}5.77 \pm 1.38 \\
3.48 \pm 1.53 \\
2.29\end{array}$ & $\begin{array}{l}4.97 \pm 0.85 \\
1.19 \pm 0.21 \\
3.78\end{array}$ & $\begin{array}{l}7.21 \pm 2.23 \\
1.22 \pm 0.44 \\
6.09\end{array}$ & $\begin{array}{l}2.14 \pm 0.33 \\
0.96 \pm 0.64 \\
1.18\end{array}$ \\
\hline $\begin{array}{l}\text { Medium-large pyramids } \\
\quad(n=60)\end{array}$ & $\begin{array}{l}2.77 \pm 0.49 \\
1.28+0.11 \\
1.49\end{array}$ & $\begin{array}{l}4.61 \pm 0.29 \\
1.43+0.14 \\
3.18\end{array}$ & $\begin{array}{l}4.01 \pm 0.61 \\
2.14 \pm 0.43 \\
1.87\end{array}$ & $\begin{array}{l}6.28 \pm 3.20 \\
1.92 \pm 0.01 \\
4.36\end{array}$ & $\begin{array}{l}4.15 \pm 0.34 \\
1.34 \pm 0.26 \\
2.81\end{array}$ & $\begin{array}{l}3.82 \pm 0.34 \\
1.26 \pm 0.12 \\
2.56\end{array}$ & $\begin{array}{l}4.04 \pm 0.64 \\
0.83 \pm 0.33 \\
3.21\end{array}$ \\
\hline & & $\begin{array}{l}\text { Dendrites } \\
1^{\circ}\end{array}$ & $2^{\circ}$ & & & & \\
\hline $\begin{array}{l}\text { Multipolars } \\
\qquad(n=14)\end{array}$ & $\begin{array}{l}2.71 \pm 0.49 \\
1.28 \pm 0.33 \\
1.43\end{array}$ & $\begin{array}{l}4.49 \pm 0.92 \\
0.88 \pm 0.16 \\
3.61\end{array}$ & $\begin{array}{l}4.09 \pm 0.72 \\
1.78 \pm 0.45 \\
2.31\end{array}$ & & & & \\
\hline
\end{tabular}

a Total PrBCM binding in grains $/ 10 \mu \mathrm{m}$ somal perimeter or dendritic length $(\bar{X} \pm \mathrm{SE})$.

${ }^{b}$ Nonspecific $\operatorname{PrBCM}$ binding in grains $10 \mu \mathrm{m}$ as above but coincubated in $10^{-6} \mathrm{M}$ atropine $(\bar{X} \pm \mathrm{SE})$.

c Specific binding ( $\bar{X}$ total minus $\bar{X}$ nonspecific).

maining synaptic structures. Examination both of cell suspensions and monolayers demonstrated that the separation of preand postsynaptic endings was complete (Figs. 2-4): Virtually no cellular debris adhered to the isolated cells and presynaptic endings were observed clinging to somata or dendritic shafts on only a few occasions. Furthermore, the plasmalemma of dissociated cells remained intact. Somewhat surprisingly, dendritic spines were not observed in any of the preparations, even though the primary, secondary, and tertiary dendrites of 8 serially sectioned neurons were examined. Instead, evaginations were occasionally present singly or in groups along the dendritic shaft (Fig. $4 A$ ); these evaginations may have represented the remaining stalk of the spine, its head having been removed during dissociation procedures. Discrete cytoplasmic densities were present along the membrane of dendritic profiles from the cell suspension (Figs. 4, $A, B$ ). It is likely that the membrane-associated densities were postsynaptic specializations of asymmetric synapses; for symmetric synapses, postsynaptic densities are probably too diffuse to be recognized after removal of the presynaptic terminal. In contrast to the isolated dendritic profiles in the cell suspension, membrane-associated densities were not seen along the soma or proximal dendrites of the serially sectioned neurons. Finally, another membrane specialization, the subsurface cisterna, was easily identified along the plasmalemma of both somata and apical dendrites in cell suspensions and monolayers (Fig. 4C).

\section{Distribution of muscarinic receptors}

Each class of neuron had PrBCM binding to somata, primary, secondary, and tertiary dendrites. Examples of PrBCM binding to medium-large pyramids, multipolar cells, and small pyramidal neurons are presented in Figures 5-7. It was clear from a comparison with atropine-blocked binding in matched series (i.e., those prepared at the same time and autoradiographed in the same way) that a large percentage of this binding was specific (Figs. 5D, 6D, 7B). In most instances PrBCM binding appeared to be evenly distributed along dendrites (Figs. $5, B, C ; 6, A, B$ ). There were cells, however, that had patches of PrBCM binding sites, and, when present on pyramids, these sites were usually on proximal parts of the apical dendritic tree (Figs. 5A, 7A).
Nonspecific binding never occurred in patches.

Specific binding $/ 10 \mu \mathrm{m}$ length of somal perimeter or dendritic length was calculated from total and nonspecific binding for cells processed in matched series, as presented in Table 1 . In this series, nonspecific binding ranged from $21 \%$ on tertiary dendrites of medium-large pyramids to $67 \%$ of total binding for somata of small pyramids. Specific binding to somata appeared to be less than that to dendrites, and some dendrites seemed to have had more binding than others. In light of the variability in the grain density on dendrites and the lower numbers of tertiary dendrites, a $2 \times 2$ factorial analysis of variance was performed to assess differences in binding within and between cell types. This analysis was performed on total and nonspecific binding to pairs of processes. Process pairs were chosen for testing on the basis of which had the largest mean differences in specific binding. Table 2 shows the results of 21 such comparisons. Statistically significant differences occurred only when somata were compared to dendrites. Similar processes of different cell types and of different-order dendrites within a cell type all had the same binding density.

Although there was generally less specific binding to somata than to dendrites in this series, 2 reservations should be raised about this difference. First, the grain density measured along the perimeter of a large sphere (i.e., soma) may not be equivalent to that measured along a slender cylinder (i.e., dendrite). An alternative calculation of grains per unit area might be considered, but grains were not evenly distributed around the soma because of differential drying of the emulsion to the exposed top and sides of the cell body. Operationally, this means that developed silver grains may or may not have been present on the top of somata but they always appeared at the perimeter. Second, in another series (Table 3), differences in specific binding between somata and primary dendrites were much smaller; for cxample, binding to multipolar somata was csscntially the same as to primary dendrites. Nonspecific binding in this series was also lower, ranging from $10 \%$ of total binding on somata of medium-large pyramids to $62 \%$ on somata of small pyramids. Mean nonspecific binding in Tables 1 and 2 was 33\% of total binding.

In conclusion, specific binding occurred to somata and den- 

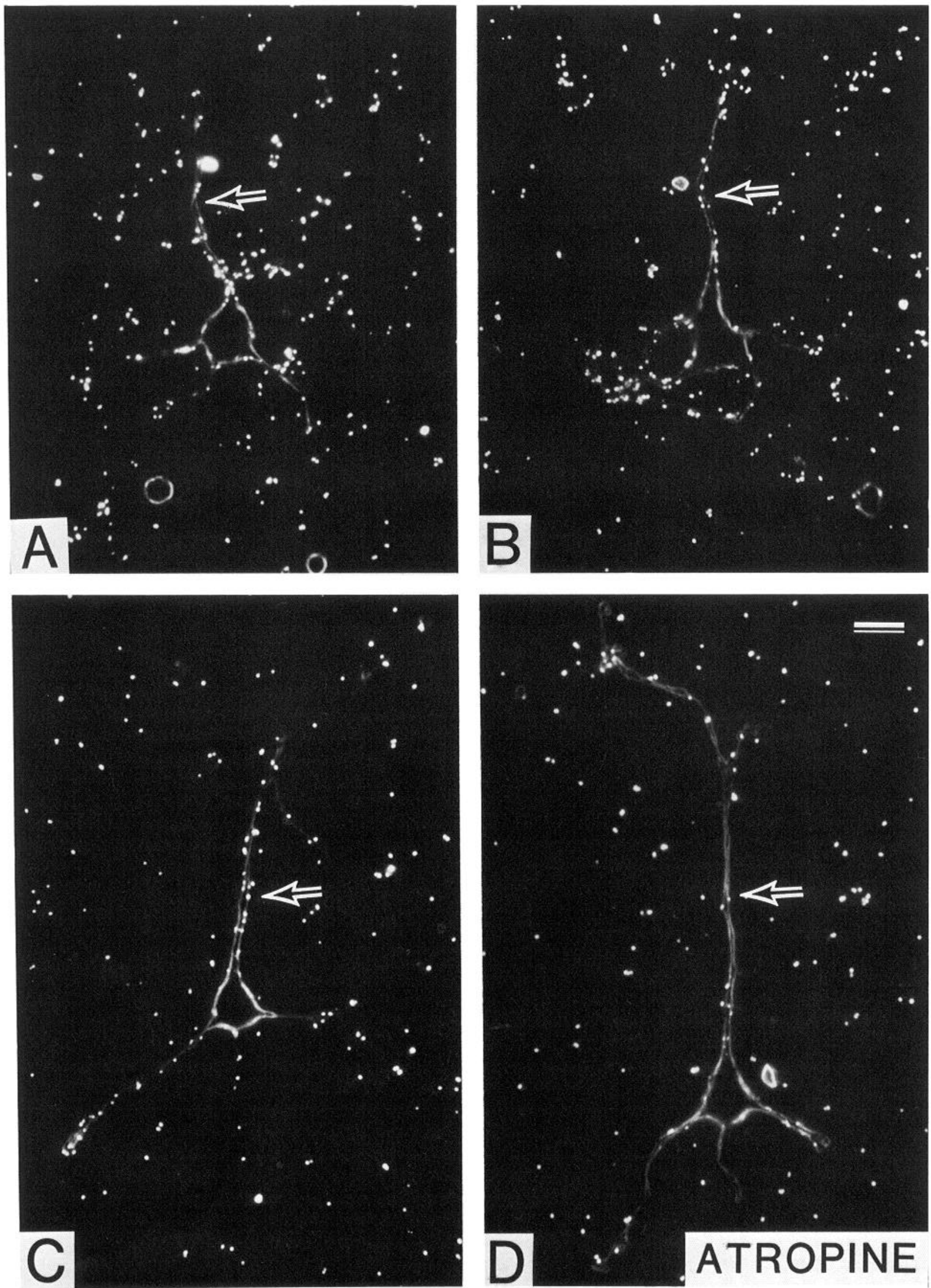

Figure 5. PrBCM binding to medium-large pyramidal neurons $(A-C)$ and block of $\operatorname{PrBCM}$ binding with $10^{-6} \mathrm{M}$ atropine $(D)$. PrBCM binding occurs on all parts of these cells, including primary apical dendrites (arrows) and somata (out of focal plane). Scale, $10 \mu \mathrm{m}$. 

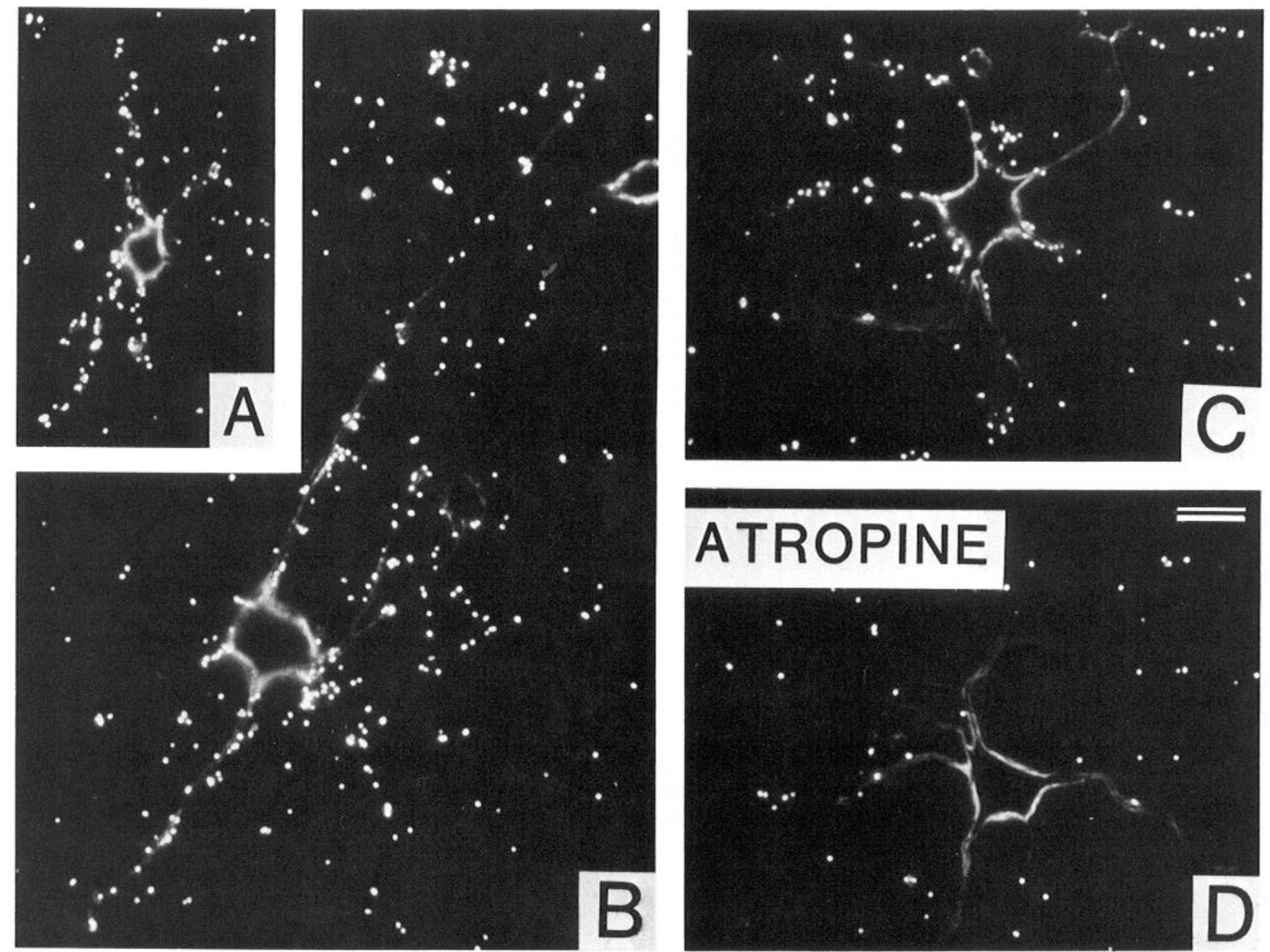

Figure 6. PrBCM binding to multipolar neurons $(A-C)$ and inhibition of this binding to a similar type of neuron with $10^{-6} \mathrm{M}$ atropine $(D)$. Calibration bar, $10 \mu \mathrm{m}$.

drites of all cortical neurons and there were no differences according to dendrite order either within or between cell types.

\section{Competition experiments}

Much PrBCM binding to dissociated neurons could be blocked with PZ. In one series of cells, PZ $(1 \mu \mathrm{M})$ differentially blocked PrBCM binding to somata and dendrites (Table 3). At this concentration, $26-42 \%$ of total somatic PrBCM binding was antagonized, $31-47 \%$ of primary dendritic binding was inhibited, and $50-61 \%$ of secondary dendritic binding was antagonized. In addition, $49 \%$ of binding on tertiary dendrites of multipolar neurons was blocked and $69 \%$ and $20 \%$ of binding to secondary basal dendrites of small and medium-large pyramids, respectively, were blocked. In another series of small pyramidal neurons, PrBCM binding was antagonized by different concentrations of $\mathrm{PZ}$ to determine the value at which $50 \%$ of total $\mathrm{PrBCM}$ binding was blocked. Figure 8 presents graphs of PrBCM binding for 2 different parts of the 37 small pyramids; Figure 7, $C$ and $D$, gives photographic examples of these cells. Total PrBCM binding was calculated for each part of every cell and the mean \pm $\mathrm{SE}$ determined. The midpoint in binding, between 0 and $10^{-8}$ M PZ, was used as an estimate of maximal binding because of the large variation in these numbers. Somatic and primary apical dendritic binding was somewhat less sensitive to $\mathrm{PZ}\left(\mathrm{IC}_{50}=6 \times\right.$
$10^{-7}$ and $9 \times 10^{-7} \mathrm{M}$, respectively) than binding to primary and secondary basal dendrites $\left(\mathrm{IC}_{50}=6.2 \times 10^{-8}\right.$ and $5.8 \times 10^{-8}$ $\mathrm{M}$, respectively).

\section{Discussion}

Isolated neurons from layers II-V in area $29 \mathrm{c}$ of rat cingulate cortex were obtained by dissociation. Examples of all neuronal cell types were harvested. Membrane and intracellular organelles were ultrastructurally intact and there was no evidence of retained presynaptic endings. All neurons had specific binding of the classical muscarinic antagonist PrBCM to somata and dendrites. Binding per unit length of dendrite did not vary significantly among cells or by order of dendritic branch. Finally, a large percentage of this binding could be blocked with PZ.

The use of enzymatically and mechanically dissociated neurons for membrane receptor binding studies prompts at least 2 important questions: What synaptic structures are retained with these procedures; and to what degree are the binding properties of the receptors affected by the dissociation process?

Morphology of dissociated neurons. The well-preserved fine structure of dissociated cortical neurons demonstrated that these cells remained normal in appearance for at least $2 \mathrm{~h}$ following removal from the brain. Furthermore, plasma membrane was intact and free of adhering presynaptic structures. Dendritic 

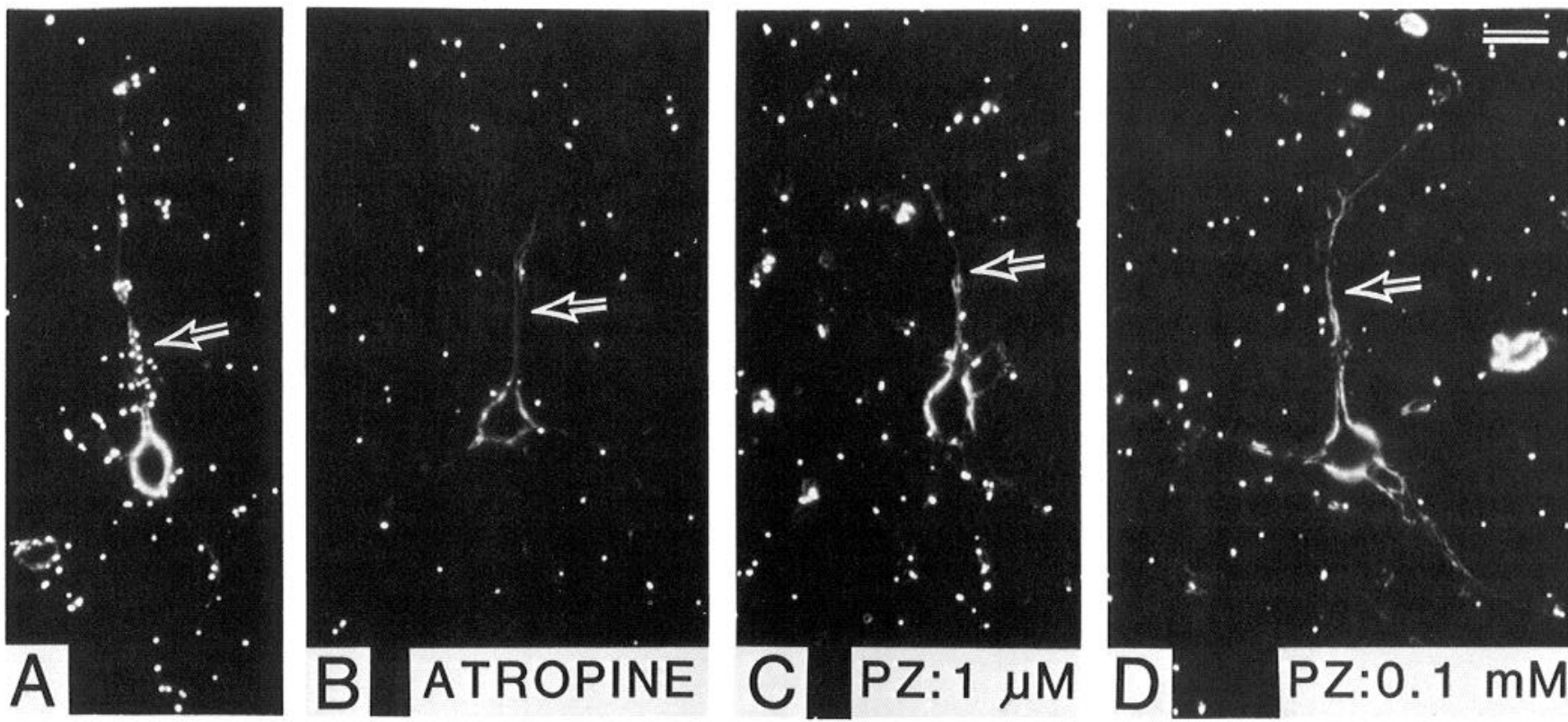

Figure 7. PrBCM binding to a small pyramidal neuron $(A)$ and blockade of this binding to similar cells with $(B)$ atropine $\left(10^{-6} \mathrm{M}\right)$ and $(C, D)$ PZ. Arrows point to primary apical dendrites. Scale in $D, 10 \mu \mathrm{m}$.

spines were not observed in our preparations. On the basis of Golgi studies of cingulate cortex, smooth surfaces would be expected for the following structures: somata, all primary apical and basal pyramidal cell dendrites, many secondary apical and basal pyramidal dendrites, most dendrites of large multipolar neurons, and some dendrites of small-to-medium multipolar neurons (Ramon y Cajal, 1911, 1922; Herrmann and Schulz, 1978; Kusicka and Schulz, 1981; Vogt and Peters, 1981; Vogt, 1985a). However, there was ultrastructural evidence that spines present on dendritic processes in the intact cortex were torn from the dendritic shafts during the isolation procedure, in that normally spinous secondary and tertiary pyramidal dendrites were spine-free after dissociation. Therefore, all PrBCM binding in these preparations was to smooth dendritic surfaces.

There was evidence of the retention of postsynaptic specializations on the shaft of formerly spinous processes, as well as on smooth dendritic processes and cell somata. This consisted of (1) the generally good preservation of the plasmalemma and plasmalemmal-associated structures, like the subsurface cisternae; (2) our observation that densities from asymmetric synapses were present on dendrites found in cell suspensions; and (3) previous reports of morphologically and physiologically intact post- and presynaptic specializations following enzymatic dissociation. In the neuromuscular junction, for instance, $\mathrm{ACh}$ sensitivity, postjunctional folds, and $\alpha$-bungarotoxin binding along the crests of the folds were retained after disjunction of the synapse and removal of the basal lamina by collagenase and protease (Betz and Sakmann, 1973; Lentz et al., 1977); for mature $\mathrm{CNS}$ neurons, functional presynaptic active zones remained at the synaptic terminals of photoreceptor cells dissociated from the retina by papain (Townes-Anderson et al., 1984, 1985). We propose that the postsynaptic structures preserved on dissociated cortical neurons were primarily from symmetric synapses. This suggestion is based on the well-known distribution of either symmetric or asymmetric synapses on either the pyramidal perikarya and dendritic trunks or the dendritic spines and smooth multipolar cells, respectively (Strick and Sterling, 1974;
Peters et al., 1976; Peters and Fairen, 1978; Peters and Proskauer, 1980; White and Rock, 1980; White and Hersch, 1981).

Technical issues. Although papain digestion and exposure to Con-A could influence receptor binding properties, there are a number of reasons for discounting these possibilities: (1) Specific binding of PrBCM occurs to dissociated neurons, and $\mathrm{IC}_{50}$ values for these cells approximate those for cryostat-sectioned material from rat cortex (Vogt et al., 1986). (2) Papain digestion does not influence the total number of quinuclidinyl benzilate sites and has only marginal effects on the apparent equilibrium constant in test tube assays (James and Klein, 1982). It has also been shown that papain concentrations at the level used in the present study do not reduce the molecular weight of PrBCM binding sites in intact pancreatic cells (Hootman et al., 1985). (3) Muscarinic receptors do not significantly bind Con-A, but instead can be affinity-purified with wheat germ agglutinin, a lectin that binds to $\mathrm{N}$-acetyl-D-glucosamine (Herron and Schimerlik, 1983; Peterson et al., 1984). It is possible, however, that these treatments contribute to nonspecific binding. Thus, nonspecific binding to dissociated neurons is about 3 times greater than that to cryostat-sectioned material mounted on chrome alum-coated slides (Vogt, 1984). Finally, Con-A has been reported to inhibit desensitization of muscarinic receptors in smooth muscle through its effects on receptor mobility (Siegel and Triggle, 1983). That the binding of Con-A to the cell surface reduces the mobility of membrane receptors (Edelman, 1976; Henis and Elson, 1981; Jung et al., 1984) has been demonstrated for a variety of cell types, including neurons (Patel and Poo, 1982). Although this property of Con-A may not be desirable for functional studies, immobilization of the receptors is advantageous for studies on structural localization of neurotransmitter receptors at the cellular level. In conclusion, there is no reason at present to assume that papain digestion or Con-A adversely affects the determination of the density, affinity, or localization of muscarinic AChR.

There are instances in which neurotransmitter uptake sites and cytoplasmic receptors have been labeled, as have postsyn- 


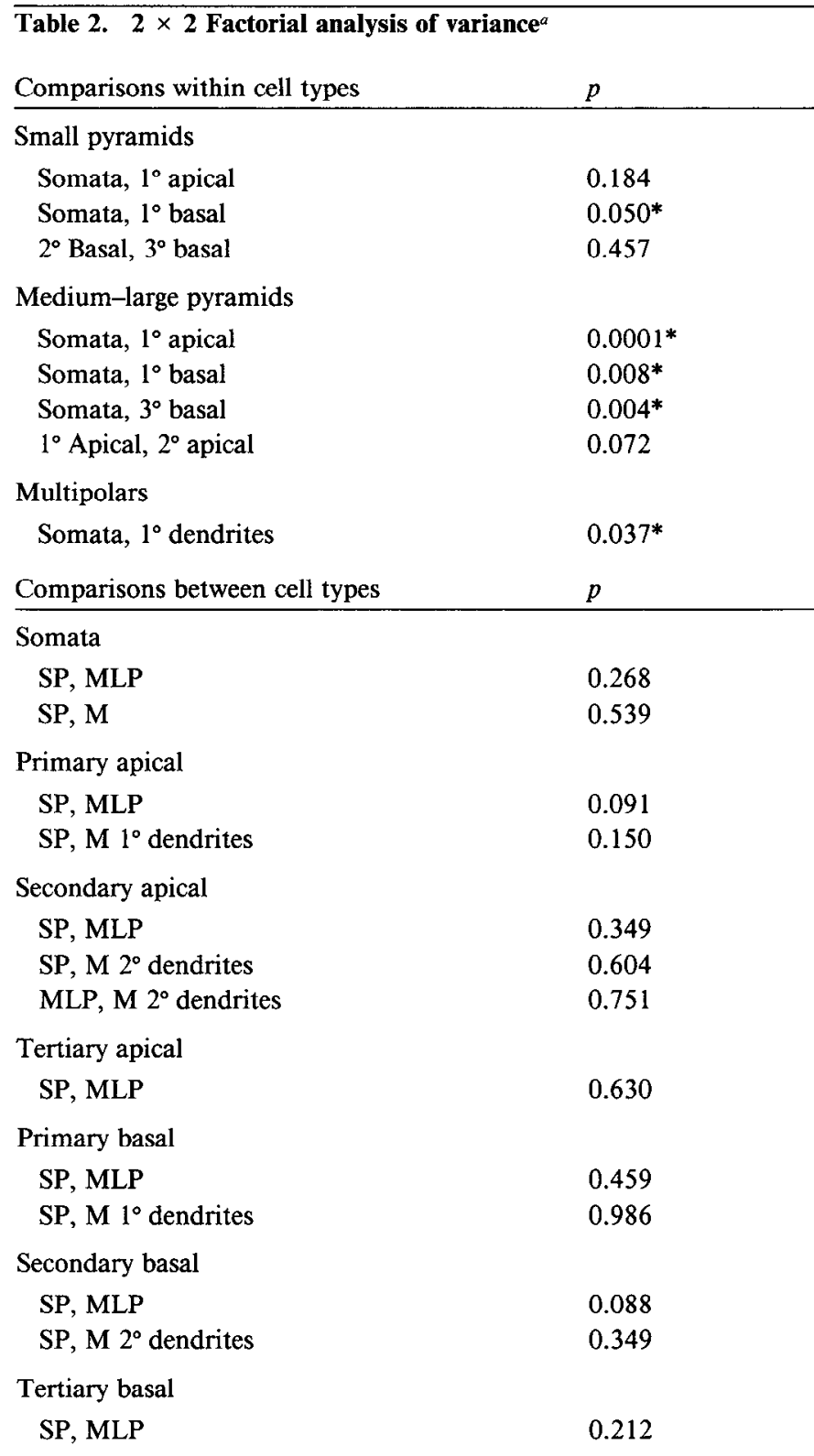

${ }^{a}$ One classification compartment is total and nonspecific binding and the other is composed of 2 cell processes. SP, small pyramids; MLP, medium-large pyramids; $\mathrm{M}$, multipolars; *, statistically significant differences at $p \leq 0.05$.

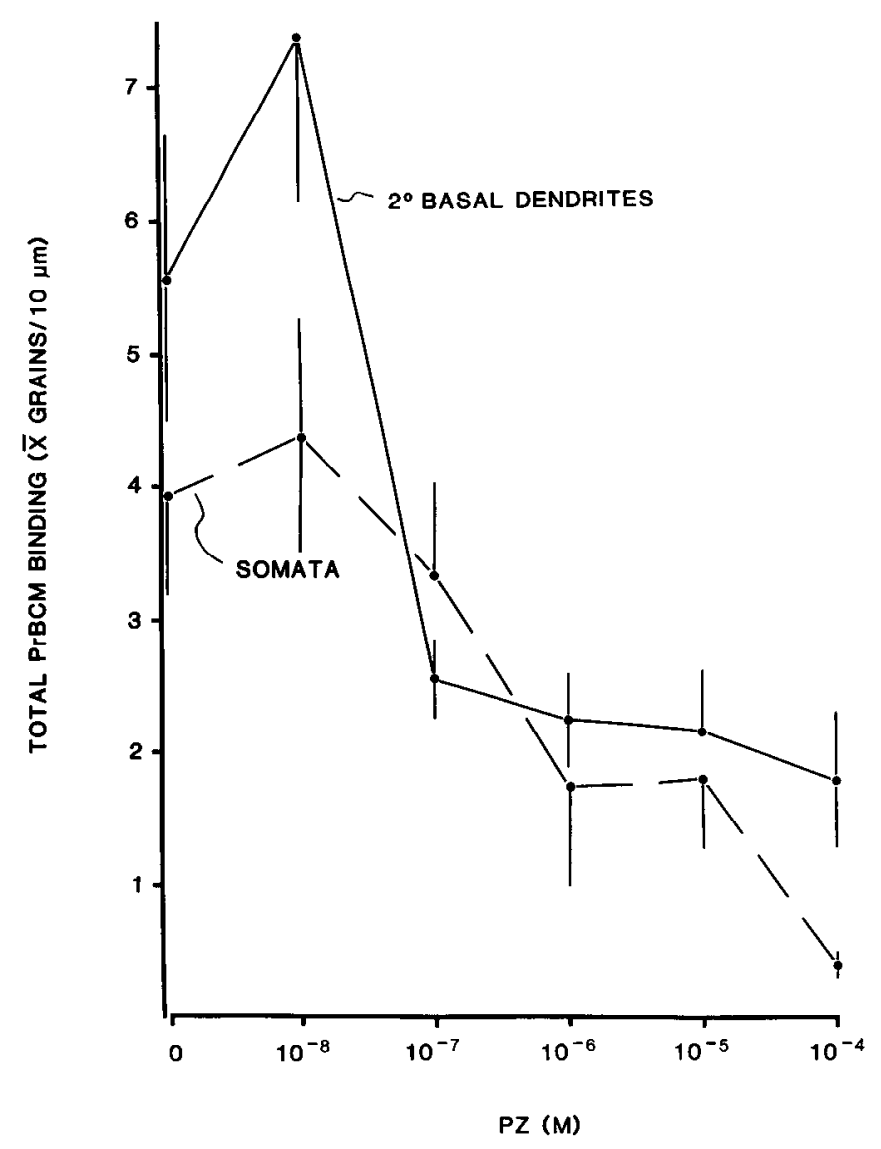

Figure 8. Binding of PrBCM to 2 parts of small pyramidal neurons coincubated in different concentrations of PZ. All 37 neurons were from the same cases and processed in the same manner. Binding to the somata of these cells was somewhat less sensitive to PZ block than was binding to basal dendrites.

aptic receptor sites in dissociated neurons. Alpha-bungarotoxin binding has been reported for a fraction of dissociated turtle retivial bipolar cells (James and Klein, 1985). This binding pattern does not correlate with electron-microscopic studies of goldfish, in which binding of $\alpha$-bungarotoxin was associated with both amacrine and ganglion cells, in addition to bipolar processes (Zucker and Yazulla, 1982). Since binding in the former study was to all processes and somata of a limited number

Table 3. Inhibition of PrBCM binding with atropine and pirenzepine

\begin{tabular}{|c|c|c|c|c|c|c|c|c|c|c|c|c|c|c|c|}
\hline \multirow[b]{2}{*}{ Cell type } & \multicolumn{5}{|c|}{ Somata } & \multicolumn{5}{|c|}{$1^{\circ}$ Apical dendrites } & \multicolumn{5}{|c|}{$2^{\circ}$ Apical dendrites } \\
\hline & Total $^{a}$ & Atr & SB & $\mathrm{PZ}$ & $\%$ & Total & Atr & SB & $\mathbf{P Z}$ & $\%$ & Total & Atr & SB & $\mathrm{PZ}$ & $\%$ \\
\hline $\begin{array}{l}\text { Small pyran } \\
\quad(n=31)\end{array}$ & 1.91 & 1.18 & 0.73 & 1.11 & 42 & 2.73 & 0.95 & 1.78 & 1.44 & 47 & 3.48 & 0.83 & 2.65 & 1.54 & 56 \\
\hline \multirow[t]{3}{*}{$\begin{array}{l}\text { Medium-la } \\
\quad(n=13)\end{array}$} & 2.42 & 0.25 & 2.17 & 1.79 & 26 & 3.31 & 0.77 & 2.54 & 2.17 & 34 & 4.26 & 0.68 & 3.58 & 1.67 & 61 \\
\hline & & & & & & \multicolumn{5}{|c|}{$1^{\circ}$ Dendrites } & \multicolumn{5}{|c|}{$2^{\circ}$ Dendrites } \\
\hline & & & & & & Total & Atr & SB & $\mathrm{PZ}$ & $\%$ & Total & Atr & SB & $\mathrm{PZ}$ & $\%$ \\
\hline $\begin{array}{l}\text { Multipolars } \\
\quad(n=13)\end{array}$ & 2.23 & 0.30 & 1.93 & 1.66 & 26 & 2.29 & 0.50 & 1.79 & 1.59 & 31 & 2.24 & 0.83 & 1.57 & 1.11 & 50 \\
\hline
\end{tabular}

${ }^{a}$ Total, grains $/ 10 \mu \mathrm{m} ; \mathrm{Atr}$, grains $/ 10 \mu \mathrm{m}$ with $10^{-6} \mathrm{M}$ atropine (nonspecific binding); SB, specific binding in grains $/ 10 \mu \mathrm{m} ; \mathrm{PZ}$, grains $/ 10 \mu \mathrm{m}$ with $10^{-6} \mathrm{M} \mathrm{PZ;} \%$, percentage of total binding blocked with $\mathrm{PZ}$. 
of bipolar cells in living retina, it appears that uptake was a predominant feature of ligand localization. Similar studies in cingulate cortex with $\alpha$-bungarotoxin in living tissue has also suggested uptake by limited groups of neurons (Hunt and Schmidt, 1978). In the present study, uptake processes were blocked with preincubation in a low concentration of glutaraldehyde that does not interfere with PrBCM binding (Rotter et al., 1979).

Distribution of $A C h R$. There is a striking correspondence betwecn the distribution of muscarinic AChR reported here and termination sites of choline acetyltransferase-positive (ChAT ${ }^{+}$) axons. Houser et al. (1985) showed that ChAT ${ }^{+}$axons form primarily symmetric synapses with smooth processes. These processes include small-to-medium-sized dendrites of unidentified origin, apical and probably basal dendrites of pyramids, and somata of nonpyramids. In the present study, specific binding of PrBCM occurred to pyramidal and multipolar neurons. Since no spines were preserved on dissociated cells, binding was to smooth surfaces and was likely associated with the postsynaptic face of symmetric synapses. A higher proportion of $\mathrm{ChAT}^{+}$ terminals form asymmetric synapses in hippocampus (Frotscher and Léránth, 1986), but they are primarily associated with spines.

One point of noncorrelation existed between AChR binding and the $\mathrm{ChAT}^{+}$study in neocortex (Houser et al., 1985). Somata of pyramids had specific PrBCM binding but were not observed to form synapses with $\mathrm{ChAT}^{+}$axons. Receptors on pyramidal somata, therefore, may not be associated with synaptic contacts and may be an example of extrajunctional receptors.

Location of $M_{1}$ sites. Evidence is accumulating that muscarinic receptors on cortical pyramids are of the $M_{1}$ variety. First, binding of PrBCM to dendritic sites is blocked by the nonclassical antagonist PZ. This inhibition occurs at concentrations (e.g., $\mathrm{IC}_{50}$ for basal dendrites, $6.2 \times 10^{8} \mathrm{M}$ ) that are consistent with high affinity $\mathrm{M}_{1}$ sites (Hammer et al., 1980; Zarbin et al., 1982; Watson et al., 1983; Luthin and Wolfe, 1984). Second, following a layer $\mathrm{Vb}-\mathrm{VI}$ ibotenic acid lesion, ${ }^{3} \mathrm{H}-\mathrm{PZ}$ binding is reduced in layer I, suggesting that the apical tufts of medium-large pyramids also have $\mathrm{M}_{1}$ receptors (B. A. Vogt and D. L. Burns, unpublished observations). Third, slow excitation of pyramids by $\mathrm{ACh}$ in vitro can be blocked with $\mathrm{PZ}$, although relatively high concentrations of $\mathrm{PZ}$ are required (McCormick and Prince, 1985, 1986).

The somewhat lower affinity of muscarinic sites on pyramidal somata than on dendrites could be accounted for in 3 ways. First, somatic sites could represent a low affinity state of the $\mathbf{M}_{1}$ sites (Potter et al., 1984). Second, we have also suggested that somatic receptors might be extrajunctional, since no $\mathrm{ChAT}^{+}$ axons have been observed forming synapses with pyramidal cell somata (Houscr et al., 1985). There is precedent for low affinity, extrajunctional receptors, as nicotinic AChR in skeletal muscle have a lower affinity in extrajunctional than in junctional sites (Brockes and Hall, 1975). Third, a limited number of $\mathrm{M}_{2}$ receptors could be present in dendritic and somatic membranes, with a higher proportion in somata.

Modulatory role of cholinergic connections. Theoretical (Rall, 1970, 1977; Horowitz, 1981) and experimental (Barretl and Crill, 1974; Carnevale and Johnston, 1982; Vogt and Gorman, 1982; Turner and Schwartzkroin, 1983) studies suggest that the influence of synaptic activity on neuronal discharge is partially related to its distance from the spike-initiation zone and the number of synapses formed by the input. Some neocortical connections can be classified as "restricted" because they terminate selectively in 1-3 layers and are, therefore, restricted to parts of the pyramidal dendritic tree. Examples of "restricted" inputs to area $29 \mathrm{c}$ are those that arise in the anterior thalamus, contralateral cortex, and ipsilateral visual cortices (Vogt et al., 1981; Vogt and Miller, 1983). In contrast, $\mathrm{ChAT}^{+}$axon terminals and AChR are scattered throughout the cortex and along the entire pyramidal cell length. Thus, cholinergic input might be termed "dispersed." It is situated so as to influence synaptic activity from other sources along the entire dendritic tree. Structural dispersion of cholinergic input would be compatible with suggestions, based on electrophysiological data, that ACh has a modulatory role in cortical function (Brown, 1983; Krnjević, 1984; McCormick and Prince, 1985).

Conclusions. In spite of the organizational complexity of CNS structures, analysis of single-cell properties can be achieved by cell-dissociation procedures. The feasibility of this approach for receptor localization in cortical neurons has now been demonstrated. In addition, such a preparation is ideally suited for studies on substrate uptake, receptor and membrane recycling, and single-ionic-channel analyses.

\section{References}

Bader, C. R., P. R. MacLeish, and E. A. Schwartz (1979) A voltageclamp study of the light response in solitary rods of the tiger salamander. J. Physiol. (Lond.) 296: 1-26.

Barrett, J. N., and W. E. Crill (1974) Influence of dendritic location and membrane properties on the effectiveness of synapses on cat motoneurons. J. Physiol. (Lond.) 293: 325-345.

Betz, W., and B. Sakmann (1973) Effects of proteolytic enzymes on function and structure of frog neuromuscular junctions. J. Physiol. (Lond.) 230: 673-688.

Brockes, J. P., and Z. W. Hall (1975) Acetylcholine receptors in normal and denervated rat diaphram muscle. II. Comparison of junctional and extrajunctional receptors. Biochemistry 14: 2100-2106.

Brown, D. A. (1983) Slow cholinergic excitation: A mechanism for increasing neuronal excitability. Trends Neurosci. 6: 302-307.

Burgen, A. S. V., C. R. Hiley, and J. M. Young (1974) The properties of muscarinic receptors in mammalian cerebral cortex. Br. J. Pharmacol. 51: 279-285.

Carnevalc, N. T., and D. Johnston (1982) Electrophysiological characterization of remote chemical synapses. J. Neurophysiol. 47: 606621

Edelman, G. M. (1976) Surface modulation in cell recognition and cell growth. Science 192: 218-226.

Estrada, C., E. Hamel, and D. N. Krause (1983) Biochemical evidence for cholinergic innervation of intracerebral blood vessels. Brain Res. 266: 261-270.

Fisher, S. K., K. A. Frey, and B. W. Agranoff (1981) Loss of muscarinic receptors and of stimulated phospholipid labeling in ibotenate-treated hippocampus. J. Neurosci. 1: 1407-1413.

Frotscher, M., and C. Léránth (1986) The cholinergic innervation of the rat fascia dentata: Identification of target structures on granule cells by combining choline acetyltransferase immunocytochemistry and Golgi imprcgnation. J. Comp. Neurol. 243: 58-70.

Hammer, R., C. P. Berrie, N. J. M. Birdsall, A. S. V. Burgen, and E. C. Hulme (1980) Pirenzepine distinguishes between different subclasses of muscarinic receptors. Nature 283: 90-92.

Henis, Y. I., and E. L. Elson (1981) Inhibition of the mobility of mouse lymphocyte surface immunoglobulins by locally bound concanavalin A. Proc. Natl. Acad. Sci. USA 78: 1072-1076.

Herrmann, C., and E. Schulz (1978) Quantitative Untersuchungen an Sternzellen im Bereich der Cingularen Rinde der Ratte. J. Hirnforsch. 19: 519-531.

Herron, G. S., and M. I. Schimerlik (1983) Glycoprotein properties of the solubilized atrial muscarinic acetylcholine receptor. J. Neurochem. 41: 1414-1420.

Hootman, S. R., T. M. Picado-Leonard, and D. B. Burnham (1985) Muscarinic acetylcholine receptor structure in acinar cells of mammalian exocrine glands. J. Biol. Chem. 7: 4186-4194.

Horowitz, B. (1981) An analytical method for investigating transient 
potentials in neurons with branching dendritic trees. Biophys. J. 36 : 155-192.

Houser, C. R., G. D. Crawford, P. M. Salvaterra, and J. E. Vaughn (1985) Immunocytochemical localization of choline acetyltransferase in rat cerebral cortex: A study of cholinergic neurons and synapses. J. Comp. Neurol. 234: 17-34.

Hunt, S., and J. Schmidt (1978) Some observations on the binding patterns of $\alpha$-bungarotoxin in the central nervous system of the rat. Brain Res. 157: 213-232.

Ito, S., and M. J. Karnovsky (1968) Formaldehyde-glutaraldehyde fixatives containing trinitro compounds. J. Cell Biol. 39: 168a.

James, W. L., and W. L. Klein (1982) Autoradiography of dendritic acetylcholine receptors: A method for study of isolated neurons of the adult central nervous system in the turtle. Neurosci. Lett. 32: 510 .

James, W. M., and W. L. Klein (1985) $\alpha$-Bungarotoxin receptors on neurons isolated from turtle retina: Molecular heterogeneity of bipolar cells. J. Neurosci. 5: 352-361.

Jung, G., R. M. Helm, C. A. C. Carraway, and K. L. Carraway (1984) Mechanism of concanavalin A-induced anchorage of the major cell surface glycoproteins to the submembrane cytoskeleton of 13762 ascites mammary adenocarcinoma cells. J. Cell Biol. 98: 179-187.

Karnovsky, M. J. (1971) Ise of ferrocyanide-reduced osmium tetroxide in electron microscopy. In Abstracts of the Eleventh Annual Meeting, The American Society of Cell Biology, p. 146.

Krnjević, K. (1984) Neurotransmitters in cerebral cortex. A general account. In Cerebral Cortex, vol. 2, E. G. Jones and A. Peters, eds., pp. 39-61, Plenum, New York.

Kuhar, M. J., and H. I. Yamamura (1976) Localization of cholinergic muscarinic receptors in rat brain by light microscopic radioautography. Brain Res. 110: 229-243.

Kuhar, M. J., N. Taylor, J. K. Wamsley, E. C. Hulme, and N. J. M. Birdsall (1981) Muscarinic cholinergic receptor localization in brain by electron microscopic autoradiography. Brain Res. 216: 1-9.

Kusicka, C., and E. Schulz (1981) Quantitative Untersuchungen von Sternzelltypen der Regio cingularis mesoneocorticalis im Vergleich 7.u den Nachbarregionen. (Mesoarchicortex und Neocortex) und nach Afferenzaus schaltung bei der Ratte. J. Hirnforsch. 22: 591-619.

Lang, W., and H. Henke (1983) Cholinergic receptor binding and autoradiography in brains of non-neurological and senile dementia of Alzheimer-type patients. Brain Res. 267: 271-280.

Lentz, T. L., J. E. Mazurkiewicz, and J. Rosenthal (1977) Cytochemical localization of acetylcholine receptors at the neuromuscular junction by means of horseradish peroxidase-labeled $\alpha$-bungarotoxin. Brain Res. 132: 423-442.

Luthin, G. K., and B. B. Wolfe (1984) Comparison of ${ }^{3} \mathbf{H}$-pirenzepine and ${ }^{3} \mathrm{H}$-quinuclidinyl benzilate binding to muscarinic cholinergic receptors in rat brain. J. Pharmacol. Exp. Ther. 228: 648-655.

MacLeish, P. R., C. J. Barnstable, and E. Townes-Anderson (1983) Use of a monoclonal antibody as a substrate for mature neurons in vitro. Proc. Natl. Acad. Sci. USA 80: 7014-7018.

Mash, D. C., D. D. Flynn, and L. T. Potter (1985) Loss of M2 muscarinic receptors in the cerebral cortex in Alzheimer's disease and experimental cholinergic denervation. Science 228: 1115-1117.

McCormick, D. A., and D. A. Prince (1985) Two types of muscarinic responses to acetylcholine in mammalian cortical neurons. Proc. Natl. Acad. Sci. USA 82: 6344-6348.

McCormick, D. A., and D. A. Prince (1986) Pirenzepine discriminates among ionic responses to acetylcholine in guinea-pig cerebral cortex and reticular nucleus of thalamus. In Subtypes of Muscarinic Receptors II. Trends Pharmacol. Sci. (Suppl.): 72-77.

Meyer, E. M., and D. H. Otero (1985) Pharmacological and ionic characterizations of the muscarinic modulating ${ }^{3} \mathrm{H}$-acetylcholine release from rat cortical synaptosomes. J. Neurosci. 5: 1202-1207.

Palacios, I. M., R. Cortes, A. Probst, and M. Karobath (1986) Mapping of subtypes of muscarinic receptors in the human brain with receptor autoradiographic techniques. In Subtypes of Muscarinic Receptors II. Trends Pharmacol. Sci. (Suppl.): 56-60.

Patel, N., and M.-m. Poo (1982) Orientation of neurite growth by extracellular electric fields. J. Neurosci. 2: 483-496.

Peters, A., and A. Fairen (1978) Smooth and sparsely-spined stellate cells in the visual cortex of the rat: A study using a combined Golgielectron microscope technique. J. Comp. Neurol. 181: 129-171.

Peters, A., and C. C. Proskauer (1980) Synaptic relationships between a multipolar stellate cell and a pyramidal neuron in the rat visual cortex. A combined Golgi-electron microscope study. J. Neurocytol. 9: 163-183.

Peters, A., S. L. Palay, and H. DeF. Webster (1976) The Fine Structure of the Nervous System: The Neurons and Supporting Cells, Saunders, Philadelphia, PA.

Peterson, G. L., G. S. Herron, M. Yamaki, D. S. Fullerton, and M. I. Schimerlik (1984) Purification of the muscarinic acetylcholine receptor from porcine atria. Proc. Natl. Acad. Sci. USA 81:4993-4997.

Potter, L. T., D. D. Flynn, H. E. Hanchett, D. L. Kalinoski, J. LuberNarod, and D. C. Mash (1984) Independent $M_{1}$ and $M_{2}$ receptors: Ligands autoradiography and functions. In Subtypes of Muscarinic Receptors I. Trends Pharmacol. Sci. (Suppl.): 22-31.

Raiteri, M., R. Leardi, and M. Marchi (1984) Heterogeneity of presynaptic muscarinic receptors regulating neurotransmitter release in the rat brain. J. Pharmacol. Exp. Ther. 228: 209-214.

Rall, W. (1970) Cable properties of dendrites and effects of synaptic location. In Excitatory Synaptic Mechanisms, P. Andersen and J. K. S. Jansen, eds., pp. 175-187, Universitetsforlag, Oslo.

Rall, W. (1977) Core conductor theory and cable properties of neurons. In Handbook of Physiology, Section 1: The Nervous System, American Physiological Society, Bethesda, MD.

Ramon y Cajal, S. (1911) Histologie du Systeme Nervoux de l'Homme et des Vertebres, Tome II, Maloine, Paris.

Ramon y Cajal, S. (1922) Estudios sobre la fina estructura de la corteza regional de los roedores. 1. Corteza suboccipital (retrosplenial de Brodmann). Trav. Lab. Biol. Univ. Madrid 20: 1-30.

Repke, H., and K. Maderspach (1982) Muscarinic acetylcholine receptors on cultured glia cells. Brain Res. 232: 206-211.

Rotter, A., N. J. M. Birdsall, A. S. V. Burgen, P. M. Field, E. C. Hulme, and G. Raisman (1979) Muscarinic receptors in the central nervous system of the rat. I. Technique for autoradiographic localization of the binding of ${ }^{3} \mathrm{H}$-propylbenzilylcholine mustard and its distribution in the forebrain. Brain Res. Rev. 1: 141-165.

Siegel, H., and D. J. Triggle (1983) Inhibition by concanavalin A, dansylcadaverine and bacitracin of muscarinic receptor-mediated desensitization in guinea-pig ileal smooth muscle. J. Pharmacol. Exp. Ther. 225:534-538

Strick, P. L., and P. Sterling (1974) Synaptic termination of afferents from the ventrobasal nucleus of the thalamus in the cat motor cortex. A light and electron microscope study. J. Comp. Neurol. 153: $77-$ 106.

Townes-Anderson, E., M. Rutten, and R. Dacheux (1984) Solitary rod photoreceptors from adult rabbit retina. J. Cell Biol. 99: 65a.

Townes-Anderson, E., P. R. MacLeish, and E. Raviola (1985) Rod cells dissociated from mature salamander retina: Ultrastructure and uptake of horseradish peroxidase. J. Cell Biol. I00: 175-188.

Turner, D. A., and P. A. Schwartzkroin (1983) Electrical characteristics of dendrites and dendritic spines in intracellularly stained CA3 and dentate hippocampal neurons. J. Neurosci. 3: 2381-2394.

Vogt, B. A. (1984) Afferent specific localization of muscarinic acetylcholine receptors in cingulate cortex. J. Neurosci. 4: 2191-2199.

Vogt, B. A. (1985a) Cingulate cortex. In Cerebral Cortex, vol. 4, A. Peters and E. G. Jones, eds., pp. 89-149, Plenum, New York.

Vogt, B. A. (1985b) Cellular localization of $\mathbf{M}_{1}$ and $\mathbf{M}_{2}$ muscarinic acetylcholine receptors in cingulate cortex. Neurosci. Abstr. I1: 1099.

Vogt, B. A., and A. L. F. Gorman (1982) Responses of cortical neurons to stimulation of corpus callosum in vitro. J. Neurophysiol. 48: $1257-$ 1273.

Vogt, B. A., and M. W. Miller (1983) Cortical connections between rat cingulate cortex and visual, motor and postsubicular cortices. $J$. Comp. Neurol. 216: 192-210.

Vogt, B. A., and A. Peters (1981) Form and distribution of neurons in rat cingulate cortex: Areas 32, 24 and 29. J. Comp. Neurol. 195: 603-625; 200: 461.

Vogt, B. A., D. L. Rosene, and A. Peters (1981) Synaptic termination of thalamic and callosal afferents in cingulate cortex of the rat. $J$. Comp. Neurol. 201: 265-283.

Vogt, B. A., E. Townes-Anderson, and D. L. Burns (1986) Distribution of $\mathrm{M}_{1}$ and $\mathrm{M}_{2}$ muscarinic acetylcholine receptors on cortical neurons and thalamic afferents. In Subtypes of Muscarinic Receptors $I I$. Trends Pharmacol. Sci. (Suppl.): 93-94.

Wamsley, J. K., M. A. Zarbin, N. J. M. Birdsall, and M. J. Kuhar (1980) Muscarinic cholinergic receptors: Autoradiographic localization of high and low affinity agonist binding sites. Brain Res. 200: 112. 
Wamsley, J. K., M. S. Lewis, W. S. Young, III, and M. J. Kuhar (1981) Autoradiographic localization of muscarinic cholinergic receptors in rat brainstem. J. Neurosci. 1: 176-191.

Wamsley, J. K., D. R. Gehlert, W. R. Roeske, and H. I. Yamamura (1984) Muscarinic antagonist binding site heterogeneity as evidenced by autoradiography after direct labeling with ${ }^{3} \mathrm{H}-\mathrm{QNB}$ and ${ }^{3} \mathrm{H}$-pirenzepine. Life Sci. 34: 1395-1402.

Watson, M., H. I. Yamamura, and W. R. Roeske (1983) A unique regulatory profile and regional distribution of ${ }^{3} \mathrm{H}$-pirenzepine binding in the rat provide evidence for distinct $M_{1}$ and $M_{2}$ muscarinic receptor subtypes. Life Sci. 32: 3001-3011.

Watson, M., W. R. Roeske, T. W. Vickroy, T. L. Smith, K. Akiyama, K. Gulya, S. P. Duckles, M. Serra, A. Adem, A. Nordberg, D. R. Gehlert, J. K. Wamsley, and H. I. Yamamura (1986) Biochemical and functional basis of putative muscarinic subtypes and its implications. In Subtypes of Muscarinic Receptors II. Trends Pharmacol. Sci. (Suppl.): 46-55.

White, E. L., and S. M. Hersch (1981) Thalamocortical synapses of pyramidal cells which project from $\mathrm{Sm} 1$ to $\mathrm{Ms} 1$ cortex in the mouse. J. Comp. Neurol. 198: 167-181.

White, E. L., and M. P. Rock (1980) Three-dimensional aspects and synaptic relationships of a Golgi-impregnated spiny stellate cell reconstructed from serial thin sections. J. Neurocytol. 9: 615-636.

Yamamura, H. I., M. J. Kuhar, D. Greenberg, and S. H. Snyder (1974) Muscarinic cholinergic receptor binding: Regional distribution in monkey brain. Brain Res. 66: 541-546.

Young, J. M., R. Hiley, and A. S. V. Burgen (1972) Homologues of benzilylcholine mustard. J. Pharm. Pharmacol. 24: 950-954.

Zarbin, M. A., J. K. Wamsley, and M. J. Kuhar (1982) Axonal transport of muscarinic cholinergic receptors in rat vagus nerve: High and low affinity agonist receptors move in opposite directions and differ in nucleotide sensitivity. J. Neurosci. 2: 934-941.

Zucker, C., and S. Yazulla (1982) Localization of synaptic and nonsynaptic nicotinic-acetylcholine receptors in the goldfish retina. J. Comp. Neurol. 204: 188-195. 